\title{
Endothelial, renal and hepatic variables in wistar rats treated with Vancomycin
}

\author{
FELIPE R. BRUNIERA ${ }^{1}$, FELIPE M. FERREIRA ${ }^{1}$, LUIZ R.M. SAVIOLI ${ }^{3}$, \\ MARCELO R. BACCI ${ }^{1}$, DAVID FEDER ${ }^{1}$, EDIMAR C. PEREIRA ${ }^{3}$, MAVILDE L.G. PEDREIRA ${ }^{3,4}$, \\ MARIA A.S. PETERLINI ${ }^{3,4}$, FÁBIO F. PERAZZO ${ }^{2}$, LIGIA A. AZZALIS ${ }^{2}$, PAULO C.P. ROSA ${ }^{2}$, \\ VIRGINIA B.C. JUNQUEIRA ${ }^{3}$, MONICAA. SATO ${ }^{1}$ and FERNANDO L.A. FONSECA ${ }^{1,2}$ \\ ${ }^{1}$ Disciplina de Farmacologia, Departamento de Morfologia, Faculdade de Medicina do ABC, \\ Av. Principe de Gales, 821, 09060-650 Santo André, SP, Brasil \\ ${ }^{2}$ Instituto de Ciências Ambientais, Químicas e Farmacêuticas, Departamento de Ciências Exatas e da Terra, \\ Universidade Federal de São Paulo, Rua Prof. Artur Riedel, 275, Jd. Eldorado, 09972-270 Diadema, SP, Brasil \\ ${ }^{3}$ Instituto de Ciências Ambientais, Químicas e Farmacêuticas, Departamento de Ciências Biológicas, \\ Universidade Federal de São Paulo, Rua Prof. Artur Riedel, 275, Jd. Eldorado, 09972-270 Diadema, SP, Brasil \\ ${ }^{4}$ Escola Paulista de Enfermagem, Universidade Federal de São Paulo, \\ Rua Sena Madureira, 1500, 04021-001 São Paulo, SP, Brasil
}

Manuscript received on May 10, 2014; accepted for publication on July 29, 2014

\begin{abstract}
Vancomycin (VCM) is indicated in combat against Gram-positive infections, but it is not considered a first-choice drug because of its adverse effects. It is believed that oxidative stress is the primary mechanism of endothelial injury and the consequent VCM toxicity, which varies from phlebitis to nephrotoxicity. Moreover, dose recommendations, dilution, rates and types of infusion are still controversial. The aim of this study was to determine the effect of different VCM dilutions in endothelial, liver and kidney injuries by biochemical parameters and histopathological analysis. Wistar rats were randomly divided into six groups and subjected to femoral vein cannulation for drug administration. Control groups received 0.9 $\mathrm{ml}$ of saline and the others received VCM $(10 \mathrm{mg} / \mathrm{Kg} /$ day $)$ at dilutions of 5.0 and $10.0 \mathrm{mg} / \mathrm{mL}$ for 3 and 7 days. Homocysteine, hs-CRP, AST, ALT, GGT, urea, creatinine, lycopene, alpha-tocopherol, beta-carotene and retinol were analyzed. Kidney, liver and cannulated femoral vein fragments were collected.This study showed alterations in ALT which featured hepatotoxicity. However, drug dilutions were not able to show changes in other biochemical parameters. In contrast, kidney and endothelium pathological changes were observed. More studies are needed to characterize VCM induced kidney and endothelium toxicity and biochemical markers able to show such morphological modifications.
\end{abstract}

Key words: Vancomycin, acute kidney injury, oxidative stress, hepatotoxicity, endothelial injury.

\section{INTRODUCTION}

Vancomycin (VCM) is a complex tricyclic glycopeptide antibiotic produced by Streptococcus

Correspondence to: Marcelo Rodrigues Bacci

E-mail:mrbacci@yahoo.com orientalis which has been used for approximately 50 years (Gupta et al. 2011). This drug became even more relevant after the onset of methicillinresistant Staphylococcus aureus (MRSA) and penicillin-resistant pneumococci infections along 
with other resistance mechanisms against betalactam antibiotics (Dehority 2010).

VCM is poorly absorbed by the gastrointestinal tract, and thus its intravenous (I.V) administration is the usual choice most of the times (ANVISA internet site 2013). A unique I.V. dose of $1 \mathrm{~g}$ in adults produces plasma concentrations of 15 to $30 \mu \mathrm{g} / \mathrm{ml}$ one hour after the infusion (Chambers 2010). The strains are considered sensitive with a minimum inhibitory concentration (MIC) $\leq 4 \mu \mathrm{g} / \mathrm{ml}$. In general it is effective against S. aureus, S. epidermidis, S. pyogenes, S. pneumoniae, streptococcus viridans, certain bacillus species, Actinomyces, Clostridium and Corynebacterium (Chambers 2010).

The mechanism of action of this drug consists in the inhibition of the bacterial cell wall biosynthesis (Gupta et al. 2011). The drug undergoes the redistribution phenomenon which makes the measurement of the peak plasma concentration difficult, and is influenced by the individual's age (ANVISA - internet site 2013). Only 5\% of the drug is metabolized and its elimination is by renal excretion (ANVISA - internet site 2013, Jelassie et al. 2011). Around $90 \%$ of the administered drug is eliminated by glomerular filtration (Chambers 2010). Its plasma half-life varies between 4 and 11 hours, with an average time of 6 hours for patients with normal renal function (ANVISA internet site 2013).

Vancomycin chloride, basically used in hospitals, is administered by the intravenous route. It is supplied as sterile powder, and directions recommend a dilution of 2.5 to $5.0 \mathrm{mg} / \mathrm{mL}$ (ANVISA internet site 2013, Jelassie et al. 2011). The drug has to be slowly infused during a period of at least 60 minutes with injection site rotation (Jelassie et al. 2011, Hicks and Hernandez 2011).

Adult dosage is $30 \mathrm{mg} / \mathrm{Kg} /$ day in 2 to 3 fractionated doses or higher, if necessary. In children, the doses range according to age (ANVISA- internet site 2013, Chambers 2010). However, a consensus regarding pediatric dosages of Vancomycin has not been reached yet (Dehority 2010, Oudin et al. 2011).
VCM adverse effects are various: hypotension, tachycardia, phlebitis, nephrotoxicity, ototoxicity, hypersensibility reactions, chills, exanthema and fever. Nevertheless, it is prescribed to combat acute Gram-positive bacterial infections caused by microorganisms that are resistant to other antimicrobials and to patients who are allergic to penicillins and cephalosporins (Chambers 2010, Hicks and Hernandez 2011).

Some studies indicate that dosage recommendations in published guidelines are frequently inadequate since they do not achieve therapeutic serum levels fast enough in patients with normal renal function (Nunn et al. 2011, Eiland et al. 2011). Other animal testing studies reveal oxidative stress induction given the increase of reactive oxygen species and the increase in the expression of complement expression genes after the use of VCM, having the onset of nephrotoxicity and phlebitis as an outcome (Oktem et al. 2005, Cetin et al. 2007, Dieterich et al. 2009). In a trial study conducted in 2010 , it was reported that the drug could directly affect the vascular tonus (Richter et al. 2010).

Recent trials suggest that the increase in number of cases of nephrotoxicity is associated with high doses of VCM, which are used to reach serum concentrations recommended by the main international guidelines in the event of treatment failure or resistance (Wong-Beringer et al. 2011).

The main risk factors related to the induction of nephrotoxicity by VCM are the use of high doses of the drug, long-term treatments, the use of VCM associated with other nephrotoxic substances, obesity and the patient's overall condition (Gupta et al. 2011).

A literature review published in 2012 reported renal toxicity related to the use of vancomycin in $10-20 \%$ and $30-40 \%$ of the cases when the drug was administered in conventional and high doses respectively. The conclusion is that the probable mechanism for such injury is associated with oxidative stress induction given the increase of reactive oxygen species (Elyasi et al. 2012). 
The aim of this study was to determine the effect of different VCM dilutions in endothelial, liver and kidney injuries in Wistar rats by biochemical (homocysteine, high sensitivity C-reactive protein, AST, ALT, GGT, urea and creatinine) and histopathological (cannulated femoral vein, liver and kidney) parameters.

\section{MATERIALS AND METHODS}

DESIGN AND ANIMALS

In this randomized controlled experimental trial, 36 male albino Wistar rats (Rattus norvegicus) weighing around $300 \mathrm{~g}$ were used. The animals were obtained from the animal facility of ABC Medical School. During the trial the rats were kept under a photoperiodic cycle of $12 \mathrm{~h}$ light per $12 \mathrm{~h}$ dark with controlled temperature, humidity, exhaust system (20 air changes per hour) and feeding. Proper animal handling and care was provided in compliance with the guidelines of the National Institute of Health in Brazil. The study was approved by the Local Animal Testing Ethics Committee under protocol number 004/2012.

\section{TREATMENT}

A total of 36 animals were randomly divided into 6 groups, weighed and housed in separate cages with ad libitum access to food and filtered water. Next the rats were intraperitoneally anesthetized with ketamine $(50 \mathrm{mg} / \mathrm{kg})$ and intramuscularly with xylazine $(10 \mathrm{mg} / \mathrm{kg})$ to be cannulated via femoral vein. The technique was performed by the insertion of a polyethylene tube (PE-3 connected to PE-1, Scientific Commodities) filled with a mixture of heparin $5000 \mathrm{IU}$ and saline in the proportion of 1:100. The tube was inserted through the subcutaneous tissue of the animal with the aid of a trochanter, and it was externalized on the back of the rat between the shoulder blades. A stainless steel pin was placed at the tip of the tube (mandrel).

The 36 animals were treated as follows: infusion of VCM $(10 \mathrm{mg} / \mathrm{kg} /$ day $)$ in dilutions of saline $5 \mathrm{mg} / \mathrm{ml}$ and $10 \mathrm{mg} / \mathrm{ml}$ for 3 days (groups 3 and 4) and for 7 days (groups 5 and 6). Day-3 and -7 control groups (groups 1 and 2 respectively) received $0.9 \mathrm{ml}$ of saline per day. In the groups treated for 3 days, samples of blood and fragments from the kidneys, liver and femoral vein cannulated on the fourth day were collected from each animal. In the groups treated for 7 days, samples of blood and fragments from the kidneys, liver and femoral vein cannulated on the eighth day were collected from each animal.

A standardization of the procedure was established. During the days that followed the cannulation process, the tube was heparinized $(0.1 \mathrm{ml})$ daily with a mixture of heparin $5000 \mathrm{IU}$ and saline in the proportion 1:100. The following procedure was adopted for the administration of VCM or saline: $0.1 \mathrm{ml}$ of water for injection (WFI) was used in order to wash the tube. Next, a solution of VCM or saline was slowly injected $(\mathrm{T}=$ 3 minutes). Finally, after 10 minutes, the tube was heparinized $(0.1 \mathrm{ml})$ and a stainless steel pin was inserted into its tip.

At the end of the experiment the animals were anesthetized with a mixture of xylazine (10 $\mathrm{mg} / \mathrm{kg}$,ip) and ketamine (100 mg/kg,ip). Blood was collected from the aorta, placed into two dry tubes and properly refrigerated until the moment of the biochemical analysis. After the animals were sacrificed, fragments from the cannulated femoral vein, kidneys and liver were collected.

BIOCHEMICAL ANALYZES

Hs-CRP and homocysteine concentrations in plasma were quantified by competitive immunoassay technique through liquid phase boiling marked as ligand binding assay. Next, chemiluminescence measurement was performed with immobilized binding protein in vitro by means of an anti-ligand detection system. Plasma quantification of AST, ALT, GGT, urea and creatinine, was determined by the colorimetric enzymatic method using 
spectrophotometric technique. Additionally, in order to evaluate the tissular response to the oxidative stress, serum levels of lycopene, alpha-tocopherol, beta-carotene and retinol were determined by the high-performance chromatographic method. All procedures were according to good clinical laboratory practices.

HistopatholOGICAL ANALYSIS

Fragments from liver, kidneys and cannulated femoral vein were fixed in a $10 \%$ buffered formaldehyde solution. The fixed samples were gradually dehydrated, paraffin-embedded and then sectioned at 5-mm thickness and stained for hematoxylineosin (HE). The pictures were taken with a Fuji digital camera (Tokio, Japan) attached with a Nikon trinocular microscope model E200 (Tokio, Japan) which were submitted to two different pathologists for analysis so that the treated groups and control could be compared. All procedures followed good pathological anatomy practices.

STATISTICAL ANALYSIS

Statistical analysis was performed with the SPSS 17.0 software package (Microsoft, USA). All variables were analyzed descriptively. The Kolmogorov-Smirnov test was used to access the normality of distribution of data. Quantitative values were shown by measures of central tendency. The ANOVA test was used for analysis of variance. Whenever possible, the post-hoc Scheffé method was applied to adjust a significance level in multiple comparisons along with the Fisher's test so that the association probability of the analyzed characteristics could be calculated. The significance level adopted for the analysis of results was $p \leq 0.05$.

\section{RESULTS}

\section{BIOCHEMICAL ANALYSIS}

Table I shows the measurement results of ALT, AST, urea, creatinine and homocysteine. Values of AST $(p=0.215)$, urea $(p=0.421)$, creatinine $(p=0.066)$ and homocysteine $(\mathrm{p}=0.117)$ did not differ among control and treated groups.

When the groups were compared, ALT value showed statistical difference $(\mathrm{p}=0.026)$. HsCRP and GGT levels did not show alterations or statistical differences among the groups.

Table II highlights the relation of intervention and control groups to serum levels of antioxidant substances. Differences between dilutions and duration of treatment were not detected for the variables used for this purpose.

HisTOPATHOLOGICAL ANALYSIS

Figure 1 shows the kidney fragment from the group that received VCM $5 \mathrm{mg} / \mathrm{ml}$ for 7 days (group 5), and it highlights minor glomerular disturbance, cytoplasmic granulations in tubular cells and interstitial inflammatory infiltrate. Mild interstitial and glomerular capillary congestions could also be observed.

Figure 1 also reveals the kidney fragment from the group that received VCM $10 \mathrm{mg} / \mathrm{ml}$ for

TABLE I

Target Organs Injury Biomarkers.

\begin{tabular}{clcccc}
\hline Group & ALT (U/l) & AST (U/l) & Urea (mg/dl) & Creatinine (mg/dl) & Homocistein $(\mu \mathrm{mol} / \mathrm{l})$ \\
\hline G1(control;3d) & $43.7 \pm 8.5$ & $87.4 \pm 16.7$ & $49.0 \pm 6.9$ & $0.5 \pm 0.1$ & $9.3 \pm 2.7$ \\
G2(control;7d) & $44.2 \pm 5.4$ & $104.5 \pm 32.9$ & $50.9 \pm 9.1$ & $0.6 \pm 0.1$ & $11.7 \pm 1.6$ \\
G3(5mg/ml;3d) & $51.0 \pm 12.8$ & $93.6 \pm 22.3$ & $46.1 \pm 6.0$ & $0.4 \pm 0.1$ & $7.1 \pm 3.7$ \\
G4(10mg/ml;3d) & $45.6 \pm 9.0$ & $110.0 \pm 33.9$ & $50.9 \pm 9.0$ & $0.5 \pm 0.1$ & $9.2 \pm 4.1$ \\
G5(5mg/ml;7d) & $64.1 \pm 21.7$ & $124.7 \pm 40.7$ & $50.0 \pm 3.8$ & $0.5 \pm 0.1$ & $11.0 \pm 2.9$ \\
G6(10mg/ml;7d) & $41.7 \pm 4.1$ & $90.0 \pm 12.2$ & $44.0 \pm 4.8$ & $0.6 \pm 0.1$ & $10.6 \pm 1.4$ \\
p Value & $\mathrm{p}=0.026^{*}$ & $\mathrm{p}=0.215$ & $\mathrm{p}=0.421$ & $\mathrm{p}=0.066$ & $\mathrm{p}=0.117$ \\
\hline
\end{tabular}

ALT:alanine aminotransferase, AST:aspartate aminotransferase. ${ }^{*} \mathrm{p}<0.05$. 
TABLE II

Analysis of Antioxidant Parameters among Groups.

\begin{tabular}{cccccccc}
\hline Variables $(\mu \mathrm{M})$ & Group 1 & Group 2 & Group 3 & Group 4 & \multicolumn{1}{c}{ Group 5 } & Group 6 & $\mathrm{p}^{l}$ \\
\hline$\alpha$-Tocopherol & $19.7 \pm 12.8$ & $25.3 \pm 9.3$ & $20 \pm 6.1$ & $20.7 \pm 4.1$ & $19.2 \pm 6.8$ & $21 \pm 7.3$ & 0.82 \\
Retinol & $2.3 \pm 0.5$ & $2.2 \pm 0.3$ & $2.5 \pm 0,3$ & $2.4 \pm 0.4$ & $2.5 \pm 0.4$ & $2.2 \pm 0.4$ & 0.58 \\
Lycopene & $0.8 \pm 0.1$ & $0.8 \pm 0.1$ & $0.8 \pm 0.05$ & $0.7 \pm 0.2$ & $0.8 \pm 0.1$ & $0.7 \pm 0.2$ & 0.37 \\
$\beta$-Carotene & $0.6 \pm 0.2$ & $0.5 \pm 0.1$ & $0.5 \pm 0.1$ & $0.5 \pm 0.1$ & $0.6 \pm 0.2$ & $0.6 \pm 0.2$ & 0.29 \\
\hline
\end{tabular}

${ }^{l}$ ANOVA test significance level. Whenever possible, the Scheffé method was applied to adjust a significance level in multiple comparisons along with the Fisher's test so that the association probability of the analyzed characteristics could be calculated. $\mathrm{N}=36$.

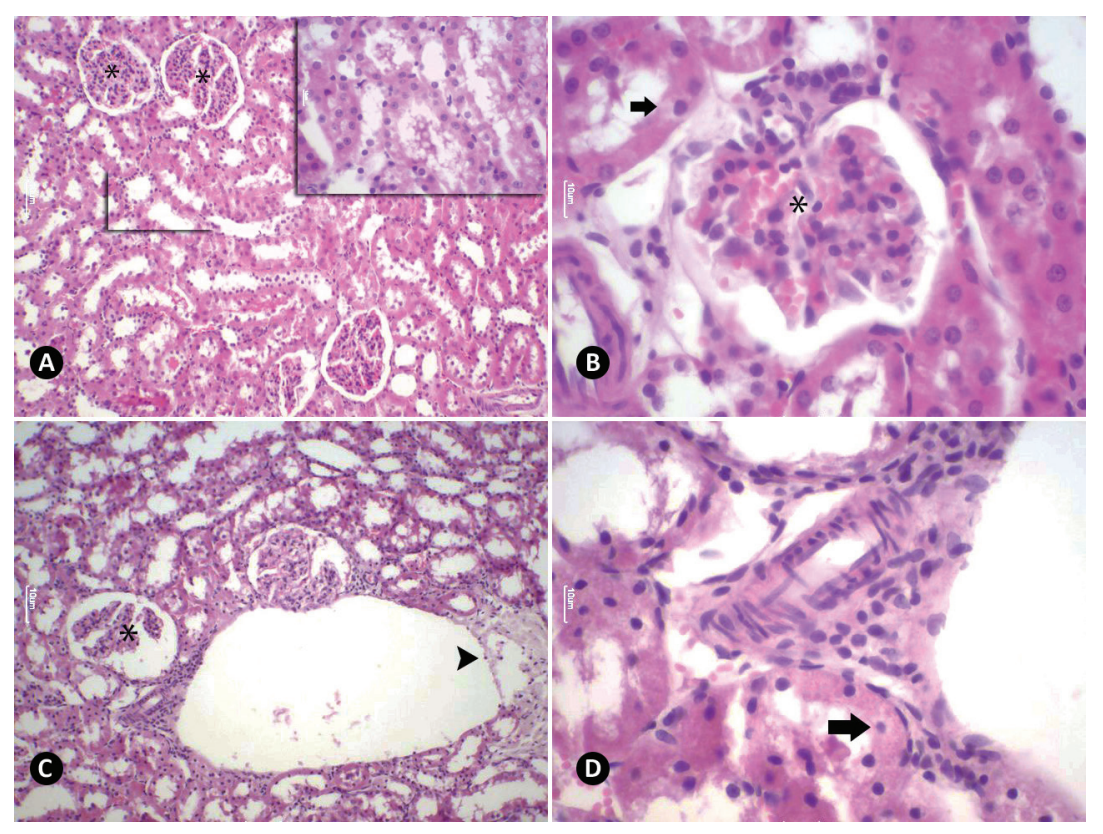

Figure 1 - A) Photomicrograph showing renal cortex from control group with preserved morphological structure along with glomerulus $(*)$ and tubules with no alterations. In the detailed view, renal tubules. HE staining, $10 \mu \mathrm{m}$. 10X magnified. B) Photomicrograph showing renal cortex from group 5, revealing a minor disturbance in the glomerular framework $\left(^{*}\right)$ and cytoplasmic granulation in tubular cells (arrow). HE staining, $10 \mu \mathrm{m}$. 40X magnified. C) Photomicrograph showing renal cortex from group 5, revealing a minor disturbance in the glomerular framework $\left(^{*}\right)$ and interstitial inflammatory infiltrate. Presence of polymorph nuclear and mononuclear leukocytes (arrowhead). HE staining, 10 $\mu \mathrm{m}$. 10X magnified. D) Photomicrograph showing renal cortex from group 6, revealing acute lesion in these structures. Tubular cells show irregularities with granules in the cytoplasm (arrow). In the interstice, an acute capillary congestion, edema and large amount of inflammatory cells can be observed. HE staining, $10 \mu \mathrm{m}$. 40X magnified. $889 \times 558 \mathrm{~mm}$ ( 72 x $72 \mathrm{DPI})$.

7 days (group 6). An acute structural injury in the renal cortex is evidenced in the figure. Tubular cells show irregularities with granules in the cytoplasm. Rupture of the Bowman's capsule and glomerular disturbance can be observed along with an acute capillary congestion with edema and intense interstitial inflammatory infiltrate.

Figure 2 presents the cannulated femoral vein fragment from groups 5 and 6, highlighting intense inflammatory infiltrate with a large amount of 

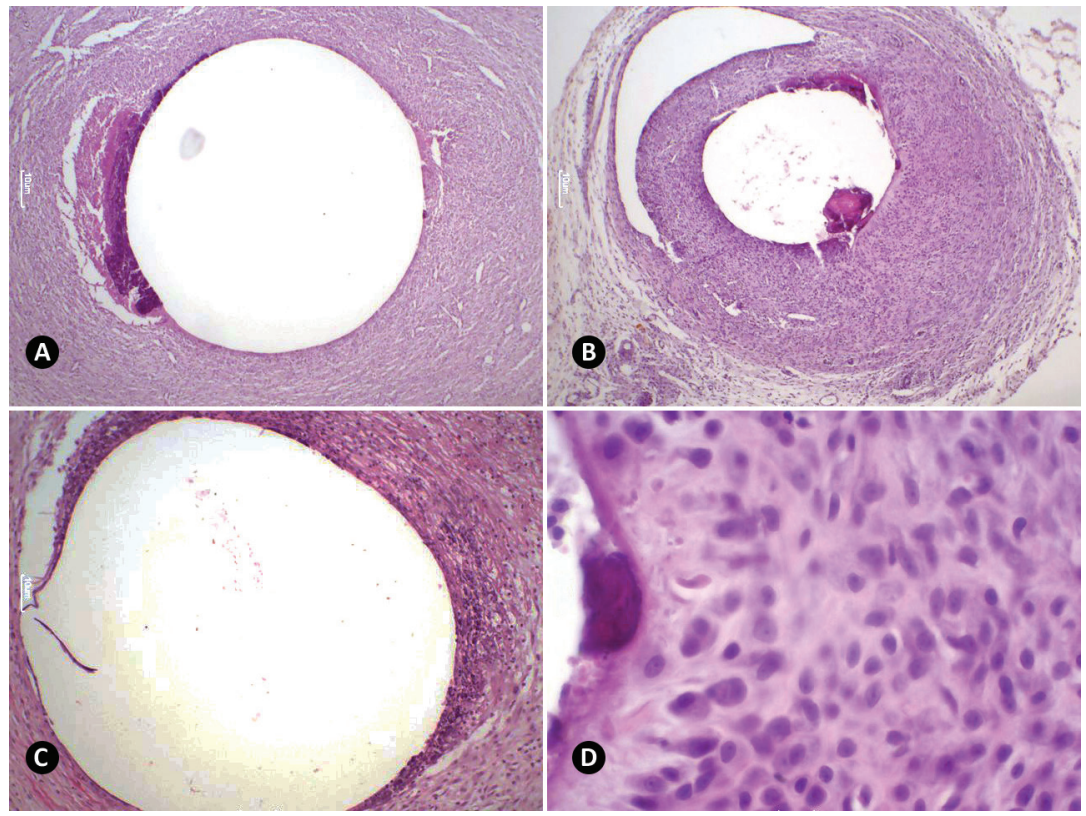

Figure 2 - A) Photomicrograph showing femoral vein sample (cannulated) from control group. In the area around the vein, inflammatory infiltrate can be observed. The presence of a darker area with multinucleated giant cells, where the cannula was inserted, is noted. HE staining, $10 \mu \mathrm{m}$. 4X magnified. B) And C) Photomicrograph showing samples of femoral vein (cannulated) from groups 6 and 5 respectively. In the area around the vein, an intense inflammatory infiltrate with predominance of plasmocytes and mastocytes. The presence of a darker area with multinucleated giant cells, where the cannula was inserted, is noted. HE staining, $10 \mu \mathrm{m} .4 \mathrm{X}$ and $10 \mathrm{X}$ magnified. D) Photomicrograph with higher magnification highlighting the inflammatory infiltrate from image B. HE staining, 10 $\mu \mathrm{m}$. 40X magnified. 889x571mm (72 x 72 DPI).

inflammatory cells, polymorphonuclear leukocytes or mononuclear cells and a mild edema. Plasmocytes and mastocytes were mostly evidenced.

The groups which were treated for 3 days (groups 3 and 4) showed minor alterations in the histopathological analysis, and the liver slides showed inconclusive results.

\section{DISCUSSION}

Our study managed to address the differences related to VCM dilutions and the duration of its administration. The animals used in the research did not present predisposing factors for endothelial, renal or hepatic injuries.

The results corresponding to endothelial injury and related to the levels of homocysteine, hs-CRP, lycopene, alpha-tocopherol, beta-carotene and retinol did not show any difference among the experimental groups, suggesting that duration, dosage and the different dilutions used in our experimental model are not able to alter such parameters. However, when the anatomopathological analysis was performed, we could observe a morphological alteration characterized by the presence of an inflammatory infiltrate associated with the intimal thickening, visualized in the vascular segment of the 7-day groups treated with different VCM dilutions.

Endothelial cells are important modulators of the normal homeostasis. One of the main effects of oxidative stress is a reduction in the nitric oxide biological activity and the resultant endothelial dysfunction (Alpers 2005, Costa et al. 2009). 
Experimental animal trials associate the use of VCM with oxidative stress induction, like the onset of phlebitis and renal injury (Oktem et al. 2005, Cetin et al. 2007, Dieterich et al. 2009, Robibaro et al. 1998a, b).

Robibaro et al. also believe that although glycopeptide antibiotics are well tolerated, high concentrations may lead to endothelial dysfunction with noticeable cell damage, which may explain the phlebitis and pain in the injection area (Robibaro et al. 1998a, b).

In an experimental trial, Richter et al showed that the drug may also directly affect the vascular tonus (Richter et al. 2010). Roszell et al affirm that patients in use of VCM present higher peripheral I.V. complication rates when compared with the administration of other antibiotics (Roszell and Jones 2010). Despite the reports, signs of endothelial injury in the analyzed biochemical parameters could not be observed.

Concerning the prevalence of renal injury caused by $\mathrm{VCM}$, it is known that there is a variation of $7-17 \%$ in patients that received the drug intravenously (Dieterich et al. 2009). Creatinine is a delayed marker and also has low sensitivity to acute kidney injury. Therefore, results based only on this parameter without histological evaluation compromise the diagnosis of renal injury due to the use of VCM (Kirsztajn 2007, Bostom et al. 2002, Shemesh et al. 1985, Vancomycin Toxicity, United States National Library of Medicine internet site 2013).

Our results also revealed that creatinine cannot evaluate renal injury; in other words, in this study, we could not establish statistical differences for this parameter. However, when it came to the anatomopathological exam, morphological alterations were detected and characterized by the presence of glomerular disturbance associated with inflammatory infiltrate and alterations in tubular cells.

Sodre et al. also affirm that no marker available today, including urea and creatinine, is completely effective to analyze renal function (Sodre et al.
2007). Therefore, many studies first try to clarify the physiopathology, and some laboratories invest in the discovery of early identification forms of renal injuries secondary to drug therapy (Dieterich et al. 2009).

In general, the VCM-induced nephrotoxicity is the acute interstitial nephritis. The presence of diffuse edema and lympho-monocitary and eosinophilic interstitial infiltrate can be observed, a fact that corroborates the data found in group 5 and, more acutely, in group 6 (Alpers 2005, Vancomycin Toxicity. United States National Library of Medicine internet site 2013, Kelly and Neilson 2012).

$\mathrm{VCM}$ is associated with minor and transitory increases in transaminases in serum in $1-5 \%$ of the cases (Liver Toxicity, United States National Library of Medicine internet site 2013). The drug is excreted by the kidneys, and only $5 \%$ of it is metabolized in the liver, a fact that could explain the absence of significant hepatic injury (Anvisa internet site 2013, Jelassie et al. 2011).

This assertion is consonant with the findings of Yoshida et al. The researchers did not observe any significant hepatic injury with the use of VCM in different doses (Yoshida et al. 2006). Chen et al., on the other hand, noticed an increase in incidence of hepatic injury with rise in ALT and AST levels related to VCM administration. However, most of the events ranged from mild to moderate intensity (Chen et al. 2011). In our study, the rats treated with different dilutions of vancomycin showed ALT alterations which characterized hepatotoxicity.

According to what was exposed above, it can be inferred that VCM dilution is a risk factor for hepatic and renal injuries, a fact that was observed due to an increase in ALT levels and in the histopathological analysis.

Besides dilution, the period of duration over which VCM is administered seems to play an important role in the development of such alterations. The endothelial stress model could not 
show alterations according to dilution, dose and duration in relation to the biochemical parameters. However, there are signs of endothelial injury visualized in the histopathological analysis of the vascular segment, especially when administration period is longer. The proposed model could determine hepatic injury which was observed due to the increased levels of ALT. Morphological alterations could be seen in some cases; however, the proposed and commonly used markers do not help in the monitoring of vancomycin toxicity.

\section{RESUMO}

A Vancomicina (VCM) é indicada no combate à infecções por Gram-positivas, porém não é considerada um agente de primeira escolha por causa dos seus efeitos adversos. Acredita-se que o estresse oxidativoéo principal mecanismo responsável pela lesão endotelial e consequente toxicidade da VCM, que varia desde flebites à nefrotoxicidade. Ademais, as recomendações de doses, diluições, taxas e tipos de infusão ainda são controversos. O objetivo deste trabalho foi determinar o efeito de diferentes diluições de VCM na lesão endotelial, hepática e renal utilizando parâmetros bioquímicos e análise histopatológica. Ratos Wistar foram divididos aleatoriamente em seis grupos e submetidos à canulação da veia femoral para a administração de medicamentos. Os grupos controle receberam $0,9 \mathrm{ml}$ de salina e os outros receberam VCM (10mg/Kg/dia) nas diluições de 5.0 e $10.0 \mathrm{mg} / \mathrm{ml}$ durante 3 e 7 dias. Homocisteína, PCR-us, AST, ALT, GGT, ureia, creatinina, licopeno, alfa-tocoferol, beta-caroteno e retinol foram analisados. Fragmentos de rins, fígado e veia femoral canulada foram coletados. Este estudo mostrou alterações na ALT, caracterizando hepatotoxicidade. Entretanto, as diluições dos medicamentos não foram capazes de evidenciar alterações nos outros parâmetros bioquímicos. Por outro lado, alterações histopatológicas foram observadas nos rins e endotélio. Mais estudos são necessários para a caracterização do efeito da VCM quanto à toxicidade nos rins e endotélio e ainda na busca de marcadores bioquímicos capazes de evidenciar tais alterações morfológicas.
Palavras-chave: Vancomicina, lesão renal, estresse oxidativo, hepatotoxicidade, lesão endotelial.

\section{REFERENCES}

ALPERS CE. 2005. The Kidney. In: Robbins SL, Cotran RS, Kumar V, Abbas AK and Fausto N (Eds), Robbins and Cotran Pathologic Basis of Disease, Rio de Janeiro: Elsevier, Rio de Janeiro, Brazil, p. 1037-1041.

ANVISA - AGÊNCIA NACIONAL DE VIGILÂNCIA SANITÁRIA. 2013. http://www4.anvisa.gov.br/base/visadoc/BM/ BM[26312-1-0]. (20 October 2013, date last accessed).

Bostom AG, Kronenberg F And Ritz E. 2002. Predictive performance of renal function equations for patients with chronic kidney disease and normal serum creatinine levels. J Am Soc Nephrol 13: 2140-2144.

Cetin H, Olgar S, OKtem F, Ciris M, Uz E, Aslan C and OZGUNER F. 2007. Novel evidence suggesting an antioxidant property for erythropoietin on vancomycininduced nephrotoxicity in a rat model. Clin Exp Pharmacol Physiol 34: 1181-1185.

ChAmBers HF. 2010. Antimicrobial agents: Protein Synthesis Inhibitors and miscellaneous antibacterial agents. In: Hardman JG and Limbird LE (Eds), Goodman and Gilman's the pharmacological basis of therapeutics, New York: McGraw-Hill, New York, USA, p. 1074-1077.

Chen Y, Yang XY, ZeCKel M, Killian C, Hornbuckle K, REGEV V AND Voss S. 2011. Risk of hepatic events in patients treated with vancomycin in clinical studies: a systematic review and meta-analysis. Drug Saf 34: 73-82.

Costa VH, Aparecido LB, Jorgetti V, Colombo FC, KREIEGER EM AND GALVÃO LJ. 2009. Oxidative stress and endothelial dysfunction in chronic kidney disease. Arq Bras Cardiol 92: 413-418.

DEHORITY W. 2010. Use of vancomycin in pediatrics. Pediatr Infect Dis J 29: 462-464.

Dieterich C, Puey A, Lin S, Swezey R, Furimsky A, FAIRChILD D, Mirsalis JC AND NG HH. 2009. Gene expression analysis reveals new possible mechanisms of vancomycin-induced nephrotoxicity and identifies gene markers candidates. Toxicol Sci 107: 258-269.

EILAND LS, ENGLISH TM AND EILAND EH. 2011. Assessment of vancomycin dosing and subsequent serum concentrations in pediatric patients. Ann Pharmacother 45: 582-589.

ELYASI S, KHALILI H, DASHTI-KHAVIDAKI S, MOHAMMADPOUR A AND BERTRAND Y. 2012. Vancomycin-induced nephrotoxicity: mechanism, incidence, risk factors and special populations. A literature review. Eur J Clin Pharmacol 68:1243-1255.

GUPTA A, BIYANI M AND KHAIRA A. 2011. Vancomycin nephrotoxicity: myths and facts. Neth J Med 69: 379-383.

Hicks RW AND HERNANDEZ J. 2011. Perioperative Pharmacology: A Focus on Vancomycin. AORN J 93: 593-599.

JELASSIE ML, BENLMOUdEN A, LeFEUVRE S, MAINARDI JL AND BILLAUD EM. 2011. Level of evidence for therapeutic drug monitoring of vancomycin. Therapie 66: 29-37. 
Kelly CJ And NeILson EG. 2012. Tubulointerstitial Diseases. In: Taal MW et al. (Eds), Brenner \& Rector's The Kidney, Philadelphia: Elsevier, Philadelphia, USA, p.1340-1342.

KIRSZTAJN GM. 2007. Assessment of glomerular filtration rate. J Bras Patol Med Lab 43: 257-264.

LIVER TOXICITY. 2013. United States National Library of Medicine. http://livertox.nlm.nih.gov. (03 May 2013, date last accessed).

Nunn Mo, Corallo Ce, Aubron C, Poole S, Dooley MJ AND CHENG AC. 2011. Vancomycin dosing: assessment of time to therapeutic concentration and predictive accuracy of pharmacokinetic modeling software. Ann Pharmacother 45: 757-763.

OKTEM F, ARSLAN MK, OZGUNER F, CANDIR O, YILMAZ HR, CIRIS M AND UZ E. 2005. In vivo evidences suggesting the role of oxidative stress in pathogenesis of vancomycininduced nephrotoxicity: protection by erdosteine. Toxicology 215: 227-233.

Oudin C, Vialet R, Boulamery A, Martin C AND Simon N. 2011. Vancomycin prescription in neonates and young infants: Toward a simplified dosage. Arch Dis Child Fetal Neonatal Ed 96: 365-370.

Richter J, Zhou J, Pavlovic D, Scheibe R, BaC VH, Blumenthal J, Hung O, Murphy MF, Whynot S AND LEHMANN C. 2010. Vancomycin and to lesser extent tobramycin have vasomodulatory effects in experimental endotoxemia in the rat. Clin Hemorheol Microcirc 46: 37-49.

Robibaro B, Vorbach H, Weigel G, Weihs A, Hlousek M, Presterl E, Georgopoulos A, Griesmacher A AND GRANINGER W. 1998a. Influence of glycopeptide antibiotics on purine metabolism of endothelial cells. Adv Exp Med Biol 431: 833-838.
Robibaro B, Vorbach H, Weigel G, Weihs A, Hlousek M, Presterl E, Georgopoulos A, Griesmacher A AND GRANINGER W. 1998b. Endothelial cell compatibility of glycopeptide antibiotics for intravenous use. J Antimicrob Chemother 41: 297-300.

Roszell S AND JONES C. 2010. Intravenous administration issues: A comparison of intravenous insertions and complications in vancomycin versus other antibiotics. J Infus Nurs 33: 112-118.

Shemesh O, Golbetz H, Kriss JP AND Myers BD. 1985. Limitations of creatinine as a filtration marker in glomerulopathic patients. Kidney Int 28: 830-838.

Sodre FL, COSTA JC AND LIMA JC. 2007. Evaluation of renal function and damage: a laboratorial challenge. J Bras Patol Med Lab 43: 329-337.

VANCOMYCIN TOXICITY. 2013. Daily Med. United States National Library of Medicine. http://dailymed.nlm.nih. gov. (20 October 2013, date last accessed)

Wong-Beringer A, Joo J, TSE E AND Beringer P. 2011. Vancomycin-associated nephrotoxicity: a critical appraisal of risk with high-dose therapy. Int J Antimicrob Agents 37: 95-101.

Yoshida M, MATZnO S, NAMBA H, NishiKATA M AND MAtsuYAmA K. 2006. Statistical analysis of the adverse effects of glycopeptide antibiotics, based on pharmacokinetics and toxicokinetics (PK/TK). J Infect Chemother 12:114-118. 
